\title{
Slime cells on the surface of Eragrostis seeds maintain a level of moisture around the grain to enhance germination
}

\author{
Agnieszka Kreitschitz ${ }^{1}$, Zerihun Tadele ${ }^{2}$ and Edyta M. Gola ${ }^{1 *}$ \\ ${ }^{1}$ Institute of Plant Biology, University of Wrocław, Kanonia 6/8, 50-328 Wrocław, Poland; ${ }^{2}$ Institute of Plant \\ Sciences, University of Bern, Altenbergrain 13, 3013 Bern, Switzerland
}

\begin{abstract}
Eragrostis is a cosmopolitan genus of the family Poaceae. Several wild species, including E. pilosa (L.) Beauv., are harvested for food, but the only cultivated crop-species is tef [E. tef (Zucc.) Trotter]. Despite its importance as a staple food and its plasticity to diverse environmental conditions, little is known about the structural and physiological strategies that adapt tef seeds to endure diverse and variable moisture regimes. Here, we report the presence of slime cells, a type of modified epidermal cell, covering the fruit of tef and its wild relative, $E$. pilosa. The slime produced by Eragrostis belongs to the 'true' slime type, since it is exclusively composed of pectins. Pectin forms uniform layers on the cell wall inner surface, which are confined by a thin cellulose layer to prevent release into the cell lumen. In the presence of water, pectins quickly hydrate, causing swelling of the slime cells. This is followed by their detachment, which may be controlled by a thin cuticle layer on the fruit surface. The ability of slime to absorb and maintain moisture around the grain is thought to be an adaptive feature for Eragrostis growing in dry habitats. This retention of water by slime may create conditions that are suitable for rapid germination.
\end{abstract}

Keywords: Eragrostis pilosa, E. tef, grain surface, pectin, slime

\section{Introduction}

The genus Eragrostis belongs to the Poaceae family (Eragrostoideae: Eragrosteae), and is represented by about 350 species, both annual and perennial (Conert, 1992; Tefera et al., 2003). This genus is widely

*Correspondence

Fax: + 48713754118

Email: edytag@biol.uni.wroc.pl distributed in dry habitats of tropical, subtropical and temperate zones of both hemispheres (Conert, 1992; Boechat and Longhi-Wagner, 2000). In Africa, several wild species of Eragrostis are used for food, including E. pilosa (L.) Beauv., especially during famine periods, but the only species cultivated as a crop is tef [E. tef (Zucc.) Trotter] (Ketema, 1997).

Tef is the predominant cereal crop in Ethiopia, where it is used as a staple food, mainly to make a special bread called injera. The seeds of tef are rich in protein, carbohydrates and minerals (Bekele et al., 1995; Tatham et al., 1996). Since the seeds are free of gluten, many people who develop severe allergies to wheat gluten can safely consume bread, or other products, made from tef. Apart from human food, the straw of tef is also an important feed for domestic animals, particularly during the dry season of the year (Tefera and Peat, 1997).

Tef is an allotetraploid plant, which is closely related to E. pilosa (Ingram and Doyle, 2003). Recent phylogenetic analysis, using molecular markers, has confirmed that E. pilosa, together with E. heteromera, may be the putative parents of tef. A morphological variation within the species suggests, however, that domestication may have taken place several times (Ingram and Doyle, 2003).

Compared to other cereal crops, tef adapts and grows well under a wide range of climatic and soil conditions (Bekele et al., 1995; Ketema, 1997; Jackman, 1999). The tef plant shows exceptional plasticity and adaptation to drought, high moisture and waterlogging (Ketema, 1997; Tefera and Peat, 1997; Assefa et al., 2001).

Although tef is an important crop that tolerates extreme environmental conditions, the basic mechanisms underlying these properties have not yet been investigated. In general, seed characteristics, tolerance to different water regimes, and oxygen availability influence the speed of seed germination and contribute to development in demanding environments. One of the well-known adaptive features of plants established in dry habitats is the ability to form slime-producing (myxospermatic, mucilaginous) diaspores (e.g. fruits 
or seeds), which are involved in plant dispersal (Vaughan et al., 1971; Grubert, 1974; Gregory and Baas, 1989; Gutterman, 1994; Huang et al., 2000; Penfield et al., 2001).

The main components of slime are pectins that quickly hydrate when wetted; this ability to absorb and maintain water may create good conditions for seed germination (Mühlethaler, 1950; Frey-Wyssling, 1959; Western et al., 2000; Penfield et al., 2001; Huang et al., 2004). The presence of slime has been reported for more than 80 angiosperm families, such as Brassicaceae, Linaceae, Malvaceae, Lamiaceae, Plantaginaceae, and Asteraceae (Young and Evans, 1973; Grubert, 1974; Mouradian, 1995; Kreitschitz and Vallès, 2007). In monocots, slime-producing diaspores have been rarely observed in families of Juncaceae and Orchidaceae (Grubert, 1974). In the family of Poaceae, where major cereal crops including tef are represented, slime has so far been reported only in the species of Crypsis and Sporobolus (Eragrostoideae) (Grubert, 1974; Tutin, 1974; Conert, 1992).

This report presents morphological features of the seeds of tef and E. pilosa, which may have importance in the adaptation of these species to dry habitats in which they usually grow.

\section{Materials and methods}

In the genus of Eragrostis, the typical fruit is a true caryopsis (grain) with a thin, single-cell layer of pericarp (the mature ovary wall), which completely adheres to the seed coat (testa) (Jackman, 1999; Boechat and Longhi-Wagner, 2003).

The morphology and structure of Eragrostis grains were compared in two improved cultivars of tef (DZ01-974 and DZ-cr-37), one collected accession (CRIC 577) and E. pilosa. The E. pilosa seeds were collected in the Ukraine near Ivanovka at the Artemisia absinthium steppe and compared with the epitype seeds of E. pilosa designated by H. Scholz (Cafferty et al., 2000; vouchers are available at Warsaw University and in the Herbarium of the Botanical Museum Berlin-Dahlem respectively). The tef lines were kindly provided by the Ethiopian Institute of Agricultural Research, and the Institute of Plant Genetics and Crop Plant Research in Gatersleben, Germany. The E. pilosa grains were provided by Professor Barbara Sudnik-Wójcikowska (Institute of Botany, Warsaw University, Poland) and Professor Hildemar Scholz (the Botanical Garden and Botanical Museum Berlin-Dahlem, FU Berlin, Germany). To determine the anatomical structure and properties of caryopses, between 15 and 20 grains of each tef line and of E. pilosa were used for each experimental treatment, with the exception of the E. pilosa epitype whose few seeds were analysed in the scanning electron microscope (SEM) to confirm the material identity.

The surface of the dry fruit was coated with a thin layer of gold (c. $5 \mathrm{~nm}$ ) in the Scancoat Six SEM Sputter Coater (Edwards, London, UK) according to the manufacturer's instructions, and then observed by SEM LEO435VP (Carl Zeiss SMT AG, Oberkochen, Germany). Based on the SEM pictures, the characteristics of the fruit surface, including the types of cells covering the fruit and their specific features, were examined.

The structure of the caryopses was analysed on standard anatomical sections ( $\mathrm{O}^{\prime}$ Brien and McCully, 1981; Ruzin, 1999). Grains of all the Eragrostis studied were fixed overnight at room temperature in FAA fixative (a mixture of formalin-acetic acid-alcohol, with 50\% ethanol, in the ratio 0.5:0.5:9), rinsed in 50\% ethanol, dehydrated in a tertiary-butyl alcohol series (each step for at least $1 \mathrm{~h}$ ), and embedded in paraffin wax (Sigma-Aldrich, Poznan, Poland). Transverse sections $5 \mu \mathrm{m}$ thick were cut and routinely stained with safranin and fast green ( $\mathrm{O}^{\prime}$ Brien and McCully, 1981; Ruzin, 1999).

The behaviour of the fruit after wetting was observed, and tests on the ability of the grain coat to hydrate were performed. Wetting experiments, with both tap and deionized water, were performed at room temperature for 1-5 min, which was sufficient for grains to hydrate. The characteristics of the tap water were determined by the authorities of the Wrockaw Water and Sewer Department (ions are given in $\mathrm{mgl}^{-1}$ ): iron 0.01 ; manganese 0.01 ; chloride 39.9 ; sulphate 83.7; nitrate 6.23; fluoride 0.15; $\mathrm{pH}$ 7.7. The chemical components of the pericarp and seed coat cells, mostly occurring in the cell wall, were identified using various staining reactions, including $0.1 \%(\mathrm{w} / \mathrm{v})$ ruthenium red, $1 \%(\mathrm{w} / \mathrm{v})$ aqueous solution of safranin, $1 \%(\mathrm{w} / \mathrm{v})$ crystal violet and $2 \%(\mathrm{w} / \mathrm{v})$ Sudan III (for references see Table 1). Dye solutions were applied to the entire grains and to the hand-cut cross-sections of grains at room temperature for $1-2 \mathrm{~min}$ to avoid overstaining the sections. The staining reaction with Sudan III was performed at $37^{\circ} \mathrm{C}$ for $10 \mathrm{~min}$. Specific cell properties were documented with an OLYMPUS BX-50 microscope connected to a DP71 camera using Cell B imaging software (Olympus, Poland).

\section{Results}

\section{Shape and size of the seed}

The size of grains in all three tef lines studied was similar. On average, the grains were $1.1-1.2 \mathrm{~mm}$ in length and about $0.6 \mathrm{~mm}$ in width, and they were oval or slightly elongated in shape (Fig. 1A, B; Table 2). Similar results were reported earlier for tef and 
Table 1. Specific staining of cell wall components

\begin{tabular}{|c|c|c|c|}
\hline Stain & Target & $\begin{array}{l}\text { Observed } \\
\text { reaction }\end{array}$ & References \\
\hline Ruthenium red & Pectin & Pink, carmine & Gerlach, 1972; Hanke and Northcote, 1975; Western et al., 2000 \\
\hline \multirow[t]{2}{*}{ Safranin } & Cellulose & Orange-red & Braune et al., 1975; O’Brien and McCully, 1981 \\
\hline & Pectin & Orange & Gerlach, 1972 \\
\hline \multirow[t]{3}{*}{ Crystal violet } & Cellulose & Dark violet & Gerlach, 1972 \\
\hline & Pectin & Violet & \\
\hline & Cuticle & Dark violet & \\
\hline Sudan III & Cuticle & Orange-red & Gerlach, 1972; O'Brien and McCully, 1981 \\
\hline
\end{tabular}

other related species (Ketema, 1997; Jackman, 1999). In contrast, the grains of $E$. pilosa were much shorter, with an average length of $0.6-0.7 \mathrm{~mm}$ and a width of $0.3 \mathrm{~mm}$ (Fig. 1C, D; Table 2).

\section{The sculpture of the grain surface}

The sculpture of the grain surface differs slightly in all the Eragrostis lines studied. The grain surfaces of cultivars DZ-01-974 (Fig. 1E) and DZ-cr-37 (Fig. 1F) were characterized by a delicate and reticulate pattern. The epidermal cells in both these lines were mostly rectangular, axially elongated, and a few times longer than wide, reaching c. $100 \mu \mathrm{m}$ in length. At the ends of the grain, they were shorter, c. $66 \mu \mathrm{m}$ long. The sculpture of the fruit surface in line DZ-01-974 was distinct and more pronounced than in cultivar DZ-cr37 (Fig. 1E, F). In the former line, the elongated outlines of epidermal cells were well defined, with protruding margins and concave outer periclinal cell walls (Fig. 1E). In addition, the longitudinal wrinkles and transverse ripples were visible on the cell surface; whereas in the latter line these features were less pronounced, and hence the surface appeared smoother (Fig. 1F).

The grain surface in the CRIC 577 line appeared smooth without a distinct sculpture, having only subtle irregular carving visible. The outlines of particular epidermal cells were indistinguishable on SEM pictures (Fig. 1G).

The pericarp epidermal cells in E. pilosa formed a very delicate reticulate pattern on the surface of the fruit with slightly marked outlines (Fig. 1C, D, I). In the majority of cases, the separate epidermal cells were indistinguishable, as the grain surface was relatively smooth with a punctate sculpture (Fig. 1H).

\section{The structure of the grain coat}

The caryopses of the three tef lines and E. pilosa are covered by a thin, single-cell layer of pericarp, which is a residue of the ovary wall, and remnants of the inner integument and the nucellar epidermis (Fig. 1J, K, Fig. 2A-E). Wetting experiments and various staining reactions target different structures in pericarp and in the seed coat, and reveal anatomical differences between the layers (Figs 2 and 3). The properties and specific targets of some of the staining solutions are summarized in Table 1 and in Fig. 30.

The pericarp was formed by epidermal cells, which loosely adhered to the seed (Fig. 1J, K). Other pericarp layers and the outer integument were not present in mature caryopses. The seed coat was formed by compressed layers of inner integument and the nucellar epidermis (Fig. 2A-E, Fig. 3A-C). As staining with safranin and ruthenium red showed, the pressed mass consisted mostly of pectin-cellulose cell walls (Fig. 3A, B, D, E). This cell mass was covered on both sides by intact cuticles (Fig. 3C, F). The inner layer of the cuticle seemed to be slightly thicker than the outer, as it also included cuticle of the nucellar epidermis (Fig. 3C). The nucellar epidermis, which formed the most internal layer, consisted of closely adhering cells (Fig. 2A-E, Fig. 3C, D).

\section{The structure and properties of the pericarp epidermal cells}

The wetting experiments showed the distinctiveness of pericarp epidermal cells, which have the specific ability to produce slime. Staining with ruthenium red (Fig. 3A, B, J, K) and safranin (Fig. 3D, E, G-I) demonstrated that the Eragrostis slime consisted of pectins. Pectins formed a homogeneous layer that was evenly distributed on the cell wall inner surface. Immediately after wetting, the epidermal slime cells began to swell. The increased pressure in the cells due to pectin hydration caused the slime cells to start expanding and, as a result, they detached from the grain surface (Fig. 2G-K). In all the Eragrostis studied, the slime cells mainly detached in the curved parts of the grain, while in the flat parts the slime cells may loosely adhere to the surface (Fig. 2G). In tef DZ-01974, the process of slime cell detachment was more distinct than in the other lines. In all the Eragrostis studied, E. pilosa included, disconnected slime cells were mostly rectangular or crescent-shaped, with blunted, rounded or pointed ends (Fig. 3G-M). 

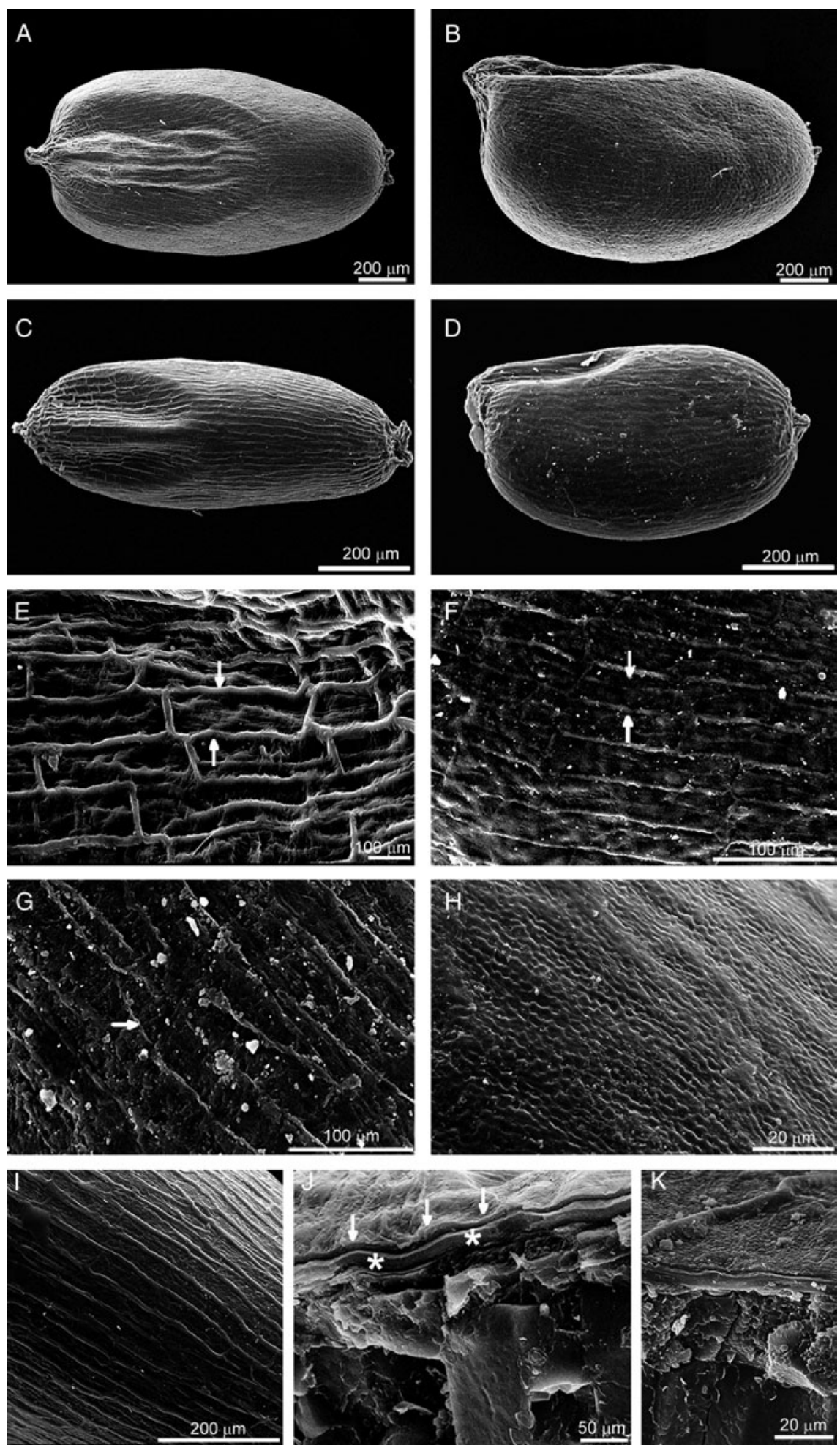

Figure 1. The SEM images of the Eragrostis grains examined. The shape of caryopses (A-D), close-ups of the surface (E-I) and the cross-section of the grain $(\mathrm{J}-\mathrm{K})$. The reticulate pattern on the grain surface is especially distinct in tef DZ-01-974 (E), and is less pronounced in other lines. The margins of the epidermal slime cells (arrows) in the former grains are protruding and the outer cell walls are concave. In other lines (F, G; arrows indicate slime cells) and E. pilosa (H, I) the sculpture is more subtle and without distinguishable outlines. The cross-section of the grain (, $\mathrm{K}$ ) shows a distinct pericarp (labelled with arrows) and the compressed layers of the inner integument are also visible (asterisks). (A, B, F, J) tef line DZ-cr-37; (E) tef line DZ-01-974; (G, K) tef line CRIC 577; (C, D, H, I) Eragrostis pilosa. 
Table 2. Seed size in Eragrostis tef lines and E. pilosa

\begin{tabular}{lcc}
\hline Line & $\begin{array}{c}\text { Mean length } \pm \text { SD } \\
(\mu \mathrm{m})\end{array}$ & $\begin{array}{c}\text { Mean width } \pm \text { SD } \\
(\mu \mathrm{m})\end{array}$ \\
\hline E. pilosa $(\mathrm{W})$ & $0.73 \pm 0.08$ & $0.33 \pm 0.05$ \\
Tef (DZ-cr-37) & $1.1 \pm 0.09$ & $0.6 \pm 0.06$ \\
Tef (DZ-01-974) & $1.2 \pm 0.07$ & $0.63 \pm 0.05$ \\
Tef (CRIC 577) & $1.2 \pm 0.07$ & $0.62 \pm 0.05$ \\
\hline
\end{tabular}

The values are given as means of 30 measurements \pm the standard deviation (SD), for E. pilosa seeds from Warsaw (W) and all tef lines.

The staining results with crystal violet, safranin and ruthenium red demonstrated the presence of distinctive layers within the cell wall of pericarp epidermal cells. Numerous bead-like thickenings were observed in the anticlinal cell walls of two neighbouring epidermal cells (Fig. 3N). The primary character of these walls and the absence of a secondary cell wall suggested that this characteristic bead-like appearance was due to the presence of primary pit fields in the hollows of the cell wall, in which a plasmodesmatal network was most probably present during seed development.

In cross-section, the epidermal cells had a more or less circular contour (Fig. 2D, K, Fig. 3A-E). Hydrated slime remained inside the cells and did not burst the walls. This may suggest the presence of a relatively scarce amount of slime and an additional cellulose layer, which delimits pectins on the inner side of the cell wall (Fig. 3N). During hydration, the swollen pectins pressed this most internal cellulosic layer of the cell wall towards the lumen of the cell. These swollen cell walls were visible as inclusions inside the cell, parallel to the outline of the cell (Fig. 3L, M). As a result, the lumen of the slime cell appeared to be narrow, almost completely tightened up by the expanded cell wall (Fig. 3C).

\section{Cuticle visualization}

Hydration experiments using deionized versus tap water demonstrated the presence of the cuticle layer on the surface of the epidermal cells (Fig. 2F-L). After treatment with tap water, the cells with a cuticle adhering to their surface were swollen and detached from the grain (Fig. 2G, H); in contrast, deionized water caused the separation and visualization of the thin membrane enclosing the swollen epidermal cells at the grain surface (Fig. 2F, I, J). This thin membrane, which was identified in staining reactions with Sudan III (specific dye for lipids) and crystal violet (Fig. 2M, $\mathrm{N}$ ), consisted of a separate, narrow layer of cuticle that covered the outer cell wall of the epidermal slime cells. This particular cuticle membrane broke up during detachment of successive epidermal cells (Fig. 2L).

\section{Discussion}

Eragrostis tef is a grass that is well adapted to diverse, often harsh environmental conditions (Ketema, 1997; Jackman, 1999). The important adaptation, reported here, is the presence of a specific pericarp structure that may facilitate the rapid germination of tef. Pericarp epidermal cells produce slime, which may be beneficial under conditions of water deficit. In the cell wall of these cells, the pectin layer may be responsible for absorption of water and for water maintenance around the diaspore during germination. Additionally, slime may facilitate attachment of tef seeds to soil. These postulated functions of slime in tef seeds correspond well with the generally recognized biological role of slime, especially in plants growing in dry habitats (Young and Evans, 1973; Grubert, 1974; Gregory and Baas, 1989; Huang et al., 2000; Penfield et al., 2001; Kreitschitz and Vallès, 2007).

The slime of Eragrostis belongs to the pectic or 'true' slime type, which consists mostly of pectins and is typically present in Plantago and Linum (Mühlethaler, 1950; Fahn and Werker, 1972), for example. The other type of slime, known as cellulosic slime, occurs in genera such as Artemisia and Salvia (Mühlethaler, 1950; Grubert, 1974; Kreitschitz and Vallès, 2007). Cellulosic slime, which contains cellulosic threads or fibrils in addition to a mass of pectins, was not detected in Eragrostis. In many plants (including Occimum, Linum, Salvia or Artemisia), the pressure caused by swollen pectins tears the cell walls down and releases slime, which subsequently forms a distinct gel-like envelope surrounding the seed (Mühlethaler, 1950; FreyWyssling, 1959; Grubert, 1974; Abeysekera and Willison, 1988; Western et al., 2000; Kreitschitz and Vallès, 2007). In Eragrostis, on the contrary, pectins are maintained inside the cell without disruption, due to the peculiar structure of the cell wall. Evenly distributed pectins on the inner surface of the cell wall are most probably confined by the additional cellulosic layer preventing the release of pectins.

The cuticle layer at the surface of tef grains, which was visualized in the hydration experiment with deionized water, may indirectly regulate germination of tef seeds by enhancing water retention. On the other hand, the prolonged retention of water around the seed may restrict the availability of oxygen to the embryo. The adverse effect of excess moisture on seed germination has been reported for Blepharis sp., where water, entirely filling the spaces between trichomes on the seed surface, limited the availability of oxygen to the embryo and considerably inhibited seed germination (Gutterman et al., 1967, 1973). Since tef grows better than other cereal crops in poorly drained soils such as Vertisols, it may suggest that the quick detachment of slime cells might be critical for tef and other Eragrostis species to supply oxygen and hasten 

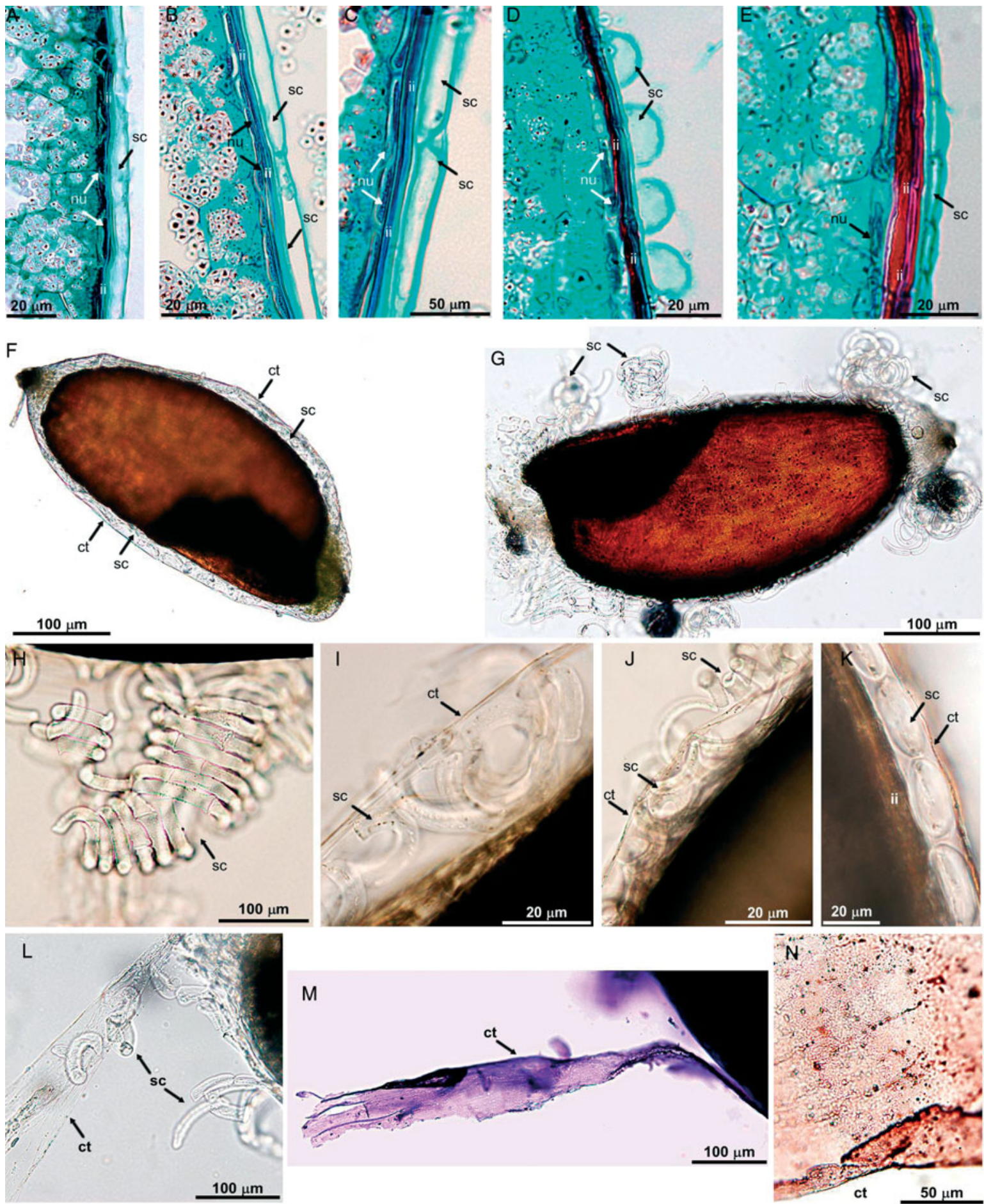

Figure 2. The structure of the Eragrostis grains: anatomical sections (A-E), pericarp behaviour in wetting experiments (F-K), and cuticle $(\mathrm{L}-\mathrm{N})$. Distinctive layers of the pericarp and seed coat are visible with longitudinally $(\mathrm{A}-\mathrm{C}, \mathrm{E})$ and transversally sectioned slime cells (sc) (D). Between the slime cells and the most internal layer, which is the nucellar epidermis (nu), the compressed cells of the inner integument (ii) are present. (F-K) different slime cell reactions depending on water type: (F, I, J) deionized water; $(\mathrm{G}, \mathrm{H}, \mathrm{K})$ tap water. When grains are wetted with deionized water, the cuticle (ct) of the pericarp cells quickly splits from the cell wall surface and forms a thin membrane enclosing the swollen epidermal slime cells. After treatment with tap water, the cuticle remains on the cell wall surface and the entire slime cells detach together with it. $(\mathrm{L}-\mathrm{N})$ Cuticle visualization: (L) split cuticle releases the slime cells; (M) staining with crystal violet; (N) staining with Sudan III. (A, J, K) tef DZ-cr-37; (B, C, H, I, L) tef DZ-01-974; (D, M, N) tef CRIC 577; (E-G) Eragrostis pilosa. For further explanation see the text. 


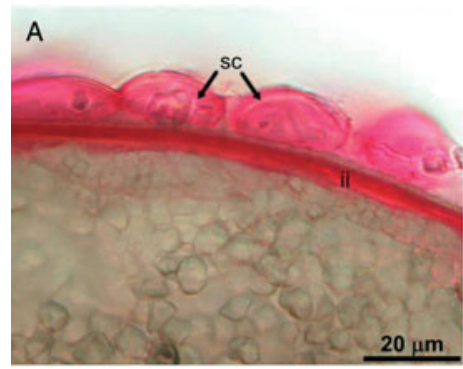

B

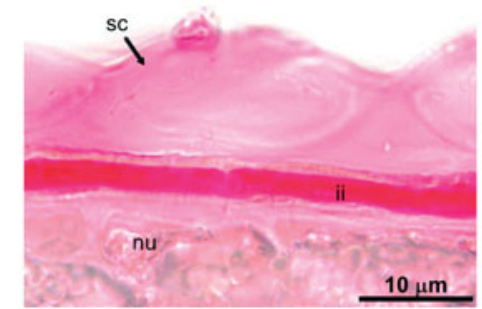

D
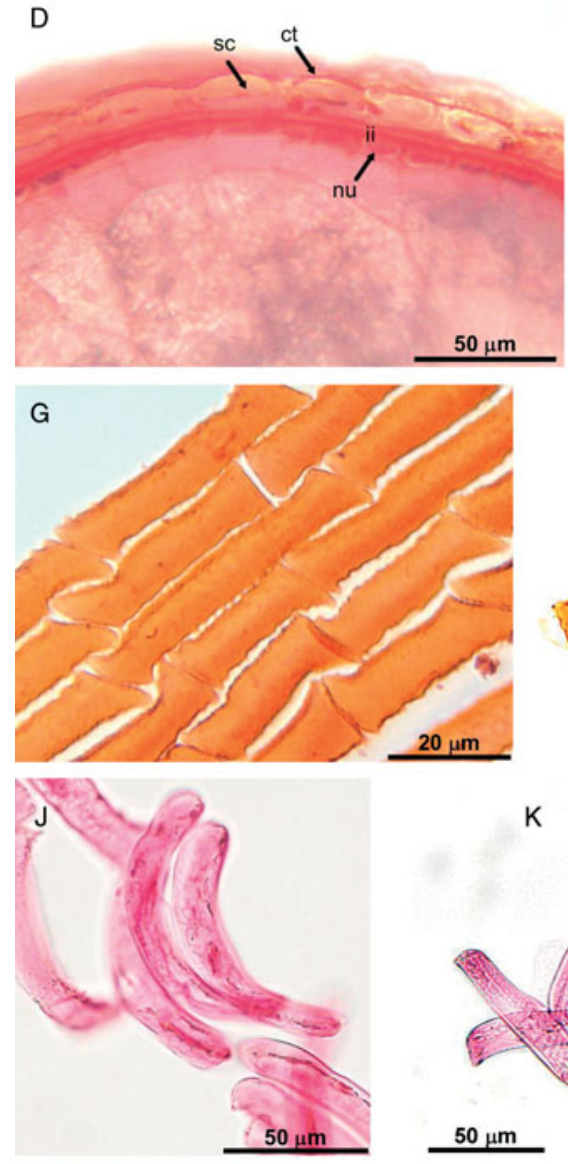

$20 \mu \mathrm{m}$

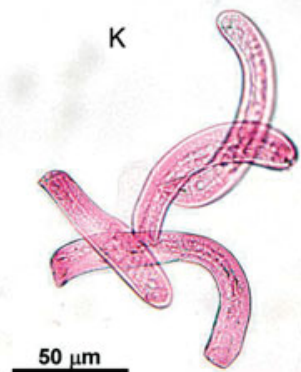

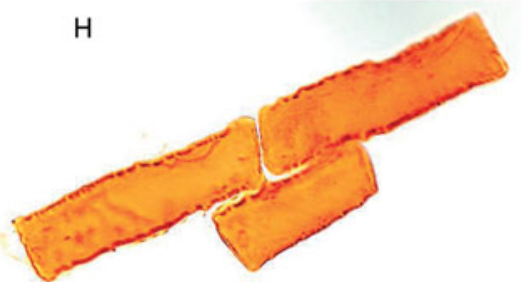

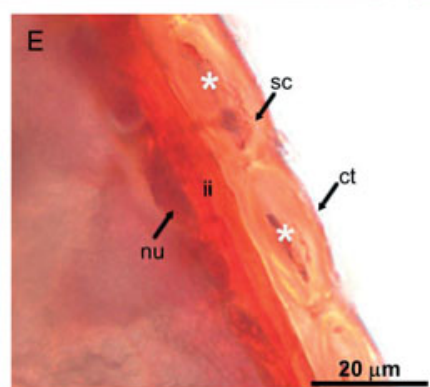

L
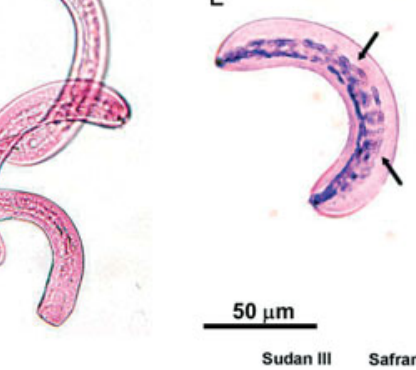

$50 \mu \mathrm{m}$

Sudan III Safranin
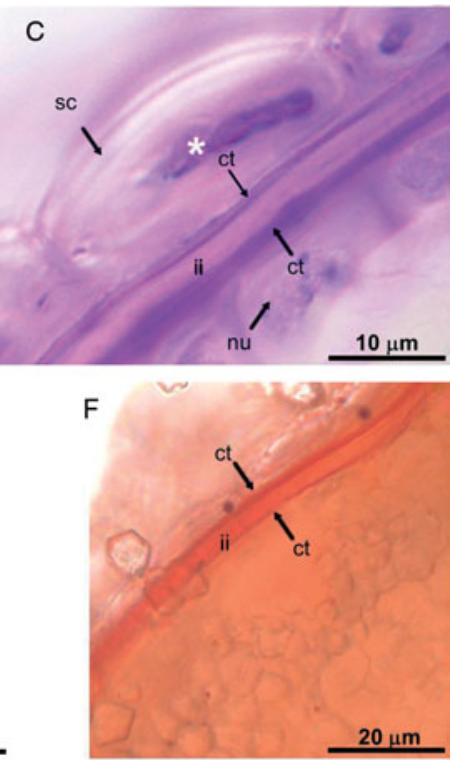

$20 \mu \mathrm{m}$

I

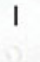

1
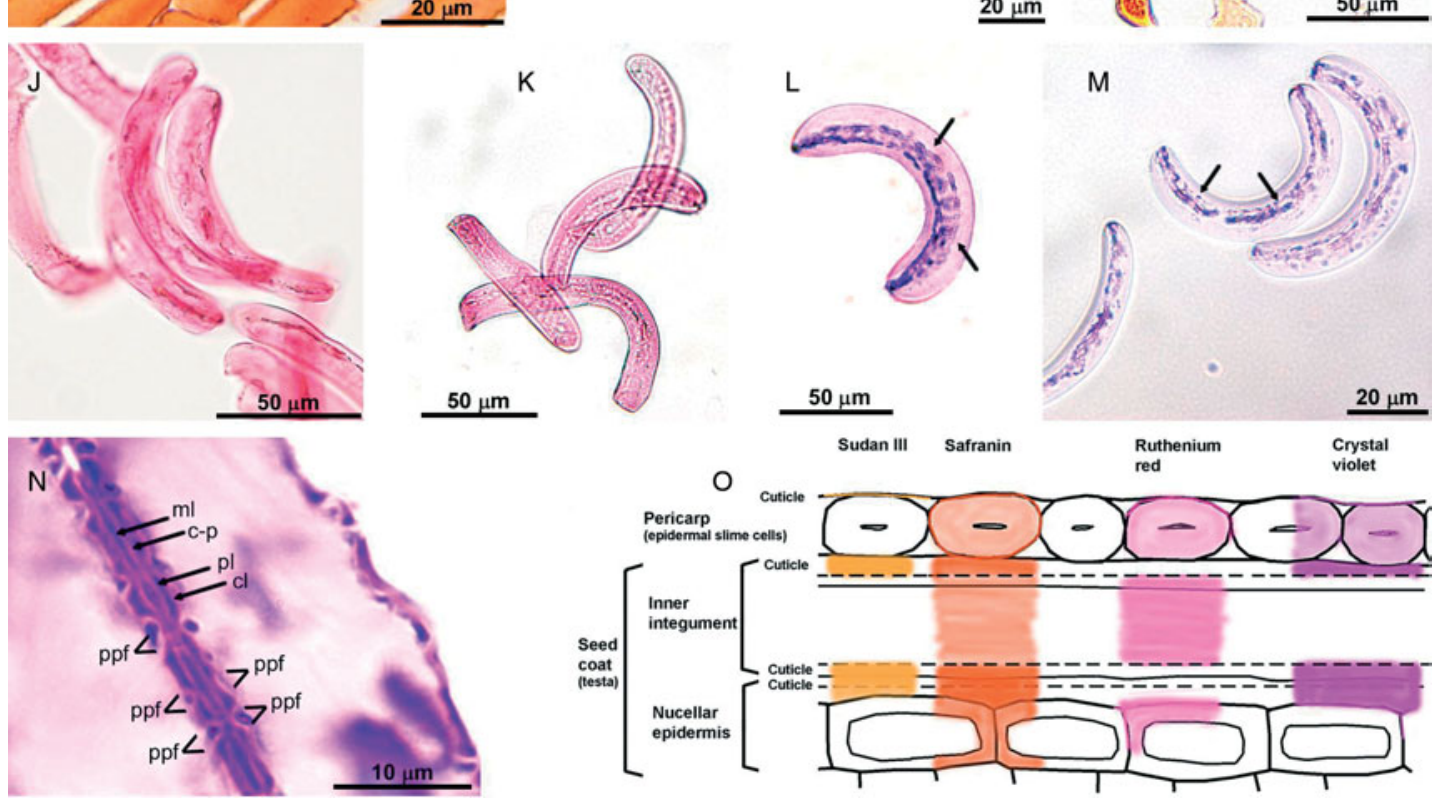

$50 \mu \mathrm{m}$
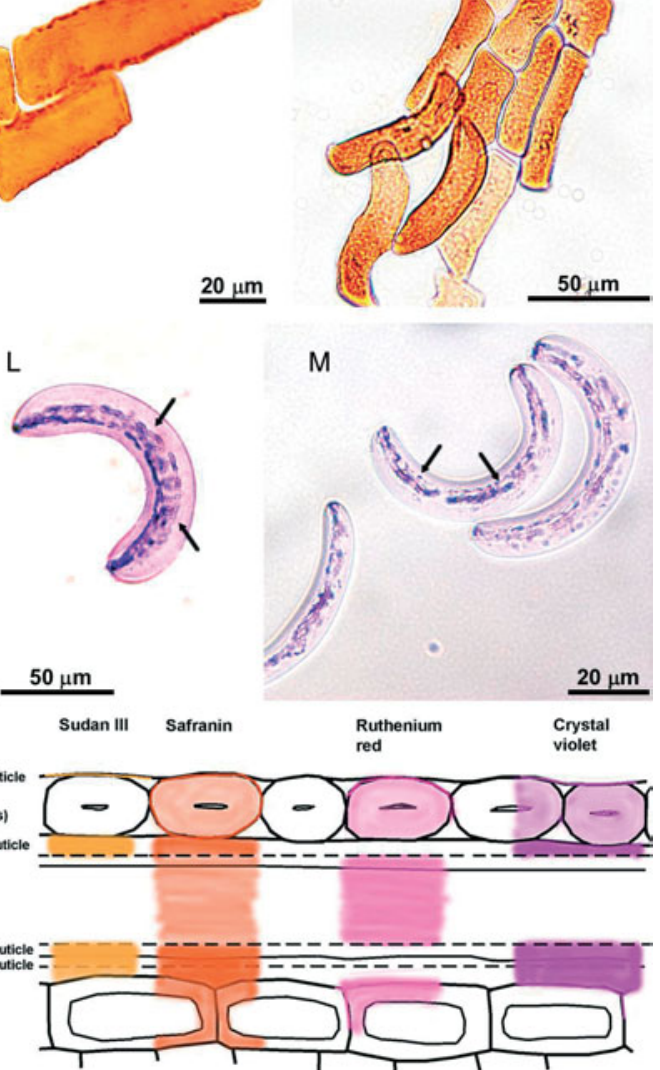

Figure 3. Slime identification and slime cell properties. Various staining reactions with ruthenium red (A, B, J, K), crystal violet $(\mathrm{C}, \mathrm{L}-\mathrm{N})$, safranin (D, E, G-I) and Sudan III (F). The lumen of the slime cell, tightened up by swollen pectins, is marked with asterisks in (C) and (E). Different shapes of epidermal slime cells are visible (G-M); inclusions inside the cells are indicated by arrows. (N) Structure of the cell wall of slime cells. Bead-like thickenings of the cell wall are formed mostly by swollen pectins (pl) delimited by the inner cellulosic layer $(\mathrm{cl})$. Due to pectin hydration the cell lumen becomes tightened up. (O) Scheme of successive layers in studied grains: pericarp, inner integument and epidermis of the nucellus. There are four cuticles present: of pericarp, of outer and inner integumental epidermis and of the nucellar epidermis. (A, C-F, L) tef DZ-cr-37; (B, G, J, N) tef DZ-01-974; (H) tef CRIC 577; (I, K, M) Eragrostis pilosa. Abbreviations: sc, slime cell; ct, cuticle; ii, inner integument; nu, nucellar epidermis; ml, middle lamella; c-p, cellulose-pectin cell wall; pl, pectin layer; cl, internal cellulose layer; ppf, primary pit fields. For further explanation see the text. 
germination, although the specific ecological studies have not yet been performed.

The relative amount of slime present in an epidermal cell may be estimated based on the sculpture of the grain surface. The amount of slime production and the shape of the wall of slime cells are related. The greater the amount of slime, the more concave the walls are likely to be. The pectin layer deposited in the cell wall dried out during seed maturation and, as a result, the cell wall shrank and became concave. The apparent outlines of the slime cells and the presence of pronounced wrinkles and ripples, as in DZ-01-974, suggest higher amounts of pectins than in the remaining tef lines studied and in $E$. pilosa, in which the grain surface seems to be smoother. Similar relationships have been reported for achenes of the Artemisia taxa differing in slime production (Kreitschitz and Vallès, 2007).

The shape of grains, and the general structure and properties of caryopses that have been reported here, show a strong resemblance between studied tef lines and E. pilosa. It has previously been suggested that E. pilosa is closely related to tef (Ingram and Doyle, 2003), and perhaps a diploid form of E. pilosa may be one of the wild ancestors of tef (Ketema, 1997). The discrepancy in the grain size, such as that observed in tef compared with E. pilosa, often occurs in plants during polyploidization (Bayer, 1998).

\section{Acknowledgements}

The authors would like to thank Professor Barbara Sudnik-Wójcikowska (Institute of Botany, Warsaw University, Poland) and Professor Hildemar Scholz (Botanical Garden and Botanical Museum BerlinDahlem, FU Berlin, Germany) for the E. pilosa caryopses; Krystyna Heller, MSc (Wrocław University of Environmental and Life Sciences) for the preparation of the SEM pictures; and to Thomas E. Harto, MA, for correction of the English. This research was supported in part by the University of Bern.

\section{References}

Abeysekera, R.M. and Willison, J.H.M. (1988) Development of helicoidal texture in the prerelease mucilage of quince (Cydonia oblonga) seed epidermis. Canadian Journal of Botany 66, 460-467.

Assefa, K., Tefera, H., Merker, A., Kefyalew, T. and Hundera, F. (2001) Quantitative trait diversity in tef [Eragrostis tef (Zucc.) Trotter] germplasm from Central and Northern Ethiopia. Genetic Resources and Crop Evolution 48, 53-61.

Bayer, R.J. (1998) New perspectives into the evolution of polyploid complexes. pp. 359-373 in van Raamsdonk, L.W.D.; den Nijs, J.C.M. (Eds) Plant evolution in man-made habitats. Proceedings of the VIIth International Symposium of the International Organization of Plant Biosystematists. Amsterdam, The Netherlands, Hugo de Vries Laboratory.
Bekele, E., Fido, R.J., Tatham, A.S. and Shewry, P.R. (1995) Heterogeneity and polymorphism of seed proteins in tef (Eragrotis tef). Hereditas 122, 67-72.

Boechat, S. de C. and Longhi-Wagner, H.M. (2000) Padrões de distribuição geográfica dos táxons brasileiros de Eragrostis (Poaceae, Chloridoideae). Revista Brasileira de Botânica 23, 177-194.

Boechat, S. de C. and Longhi-Wagner, H.M. (2003) Análise do fruto em espécies Eragrostis Wolf (Poaceae). Iheringia, Série Botanica 58, 131-168.

Braune, W., Leman, A. and Taubert, H. (1975) Praktikum z anatomii roślin. Warszawa, Państwowe Wydawnictwo Naukowe.

Cafferty, S., Jarvis, C.E. and Turland, N.J. (2000) Typification of Linnaean plant names in the Poaceae (Gramineae). Taxon 49, 239-260.

Conert, H.J. (1992) Eragrostoideae. pp. 75-120 in Hegi, G. (Ed.) Ilustierte Flora von Mittel-Europa. Bd. I, Vol. 3. Spermatophyta: Angiospermae: Monocotyledones 1(2) Poaceae. Berlin, Parey Buchverlag.

Fahn, A. and Werker, E. (1972) Anatomical mechanisms of seed dispersal. pp. 151-221 in Kozlowski, T.T. (Ed.) Seed biology. Volume I. Importance, development and germination. New York, Academic Press.

Frey-Wyssling, A. (1959) Die Pflanzliche Zellwand. Berlin, Springer Verlag.

Gerlach, D. (1972) Zarys mikrotechniki botanicznej. Warszawa, Państwowe Wydawnictwo Rolne i Leśne.

Gregory, M. and Baas, P. (1989) A survey of mucilage cells in vegetative organs of the dicotyledons. Israel Journal of Botany 38, 125-174.

Grubert, M. (1974) Studies on the distribution of myxospermy among seeds and fruits of Angiospermae and its ecological importance. Acta Biologica Venezuelica 8, 315-551.

Gutterman, Y. (1994) Strategies of seed dispersal and germination in plants inhabiting deserts. Botanical Review 60, 373-425.

Gutterman, Y., Witztum, A. and Evenari, M. (1967) Seed dispersal and germination in Blepharis persica (Burm.) Kuntze. Israel Journal of Botany 16, 213-234.

Gutterman, Y., Witztum, A. and Heydecker, W. (1973) Studies on the surfaces of desert plant seeds. II. Ecological adaptations of the seeds of Blepharis persica. Annals of Botany 37, 1051-1055.

Hanke, D.E. and Northcote, D.H. (1975) Molecular visualization of pectin and DNA by ruthenium red. Biopolymers 14, 1-17.

Huang, Z., Gutterman, Y. and Hu, Z. (2000) Structure and function of mucilaginous achenes of Artemisia monosperma inhabiting the Negev desert of Israel. Israel Journal of Plant Sciences 48, 255-266.

Huang, Z., Gutterman, Y. and Osborne, D.J. (2004) Value of the mucilaginous pellicle to seeds of the sand-stabilizing desert woody shrub Artemisia sphaerocephala (Asteraceae). Trees 18, 669-676.

Ingram, A.L. and Doyle, J.J. (2003) The origin and evolution of Eragrostis tef (Poaceae) and related polyploids: evidence from nuclear waxy and plastid rps16. American Journal of Botany 90, 116-122.

Jackman, N.D. (1999) Tef and finger millet: archaeobotanical studies of two indigenous East African cereals. MA Thesis, Simon Fraser University, Canada. 
Ketema, S. (1997) Tef. Eragrostis tef (Zucc.) Trotter. Promoting the conservation and use of underutilized and neglected crops. Vol. 12. Gatersleben, Institute of Plant Genetics and Crop Plant Research; Rome, International Plant Genetic Resources Institute.

Kreitschitz, A. and Vallès, J. (2007) Achene morphology and slime structure in some taxa of Artemisia L. and Neopallasia L. (Asteraceae). Flora 202, 570-580.

Mouradian, L.G. (1995) Comparative morpho-anatomical investigation of the achenes of Filifolium Kitam. and related genera. pp. 41-49 in Hind, D.J.N.; Jeffrey, C.; Pope, G.V. (Eds) Advances in Compositae. Systematics. Kew, Royal Botanic Gardens.

Mühlethaler, K. (1950) The structure of plant slimes. Experimental Cell Research 1, 341-350.

O'Brien, T.P. and McCully, M.E. (1981) The study of plant structure principles and selected methods. Melbourne, Australia, Termarcarphi Pty. Ltd.

Penfield, S., Meissner, R.C., Shoue, D.A., Carpita, N.C. and Bevan, M.W. (2001) MYB61 is required for mucilage deposition and extrusion in the Arabidopsis seed coat. Plant Cell 13, 2777-2791.

Ruzin, S.E. (1999) Plant microtechnique and microscopy. New York, Oxford University Press.

Tatham, A.S., Fido, R.J., Moore, C.M., Kasarda, D.D., Kuzmicky, D.D., Keen, J.N. and Shewry, P.R. (1996) Characterisation of the major prolamins of tef (Eragrostis tef) and finger millet (Eleusine coracana). Journal of Cereal Science 24, 65-71.

Tefera, H. and Peat, W.E. (1997) Genetics of grain yield and other agronomic characters in tef (Eragrostis tef Zucc. Trotter). II. The triple test cross. Euphytica 96, 193-202.

Tefera, H., Assefa, K., Hundera, F., Kefyalew, T. and Teferra, T. (2003) Heritability and genetic advance in recombinant inbred lines of tef (Eragrostis tef). Euphytica 131, 91-96.

Tutin, T.G. (1974) Eragrostis. pp. 256-258 in Tutin, T.G.; Heywood, V.H.; Burges, N.A.; Moore, D.M.; Valentino, D.H.; Walters, S.M.; Webb, D.A. (Eds) Flora Europaea. Volume 5. Alismataceae to Orchidaceae (Monocotyledones). Cambridge, Cambridge University Press.

Vaughan, J.G., Whitehouse, F.L.S. and Whitehouse, J.M. (1971) Seed structure and the taxonomy of the Cruciferae. Botanical Journal of the Linnean Society 64, 383-409.

Western, T.L., Debra, J.S. and Haughn, G.W. (2000) Differentiation of mucilage secretory cells of the Arabidopsis seed coat. Plant Physiology 122, 345-355.

Young, J.A. and Evans, R.A. (1973) Mucilaginous seed coats. Weed Science 21, 52-54.

Received 4 March 2008 accepted after revision 19 October 2008 (C) 2009 Cambridge University Press 